\title{
ANTIGENIC AND GENETIC CHARACTERIZATION OF THE FIRST RABIES VIRUS ISOLATED FROM THE BAT Eumops perotis IN BRAZIL
}

\begin{abstract}
SUMMARY
Although the main transmitters of rabies in Brazil are dogs and vampire bats, the role of other species such as insectivorous and frugivorous bats deserves special attention, as the rabies virus has been isolated from 36 bat species. This study describes the first isolation of the rabies virus from the insectivorous bat Eumops perotis. The infected animal was found in the city of Ribeirão Preto, São Paulo. The virus was identified by immunofluorescence antibody test (FAT) in central nervous system (CNS) samples, and the isolation was carried out in N2A cell culture and adult mice. The sample was submitted to antigenic typing using a panel of monoclonal antibodies (CDC/Atlanta/USA). The DNA sequence of the nucleoprotein gene located between nucleotides 102 and 1385 was aligned with homologous sequences from GenBank using the CLUSTAL/W method, and the alignment was used to build a neighbor-joining distance-based phylogenetic tree with the K-2-P model. CNS was negative by FAT, and only one mouse died after inoculation with a suspension from the bat's CNS. Antigenic typing gave a result that was not compatible with the patterns defined by the panel. Phylogenetic analysis showed that the virus isolated segregated into the same cluster related to other viruses isolated from insectivorous bats belonging to genus Nyctinomops ssp. (98.8\% nucleotide identity with each other).
\end{abstract}

KEYWORDS: Rabies; Chiroptera; RT-PCR; Sequence analysis.

\section{INTRODUCTION}

Rabies is an infectious disease caused by a Lyssavirus that belongs to the Rhabdoviridae family and infects all mammals. The main animal reservoirs are members of the orders Chiroptera and Carnivora. Bats are nocturnal animals and belong to the order Chiroptera, which consists of 18 families. The suborder Megachiroptera contains just one family, which is only found in the Old World. The suborder Microchiroptera is found throughout the world and consists of 17 families, 157 genera and 928 species $^{22}$.

There are approximately 172 species of bats in Brazil, and according to data from the São Paulo State Rabies Control Program, the rabies virus has been isolated in a total of 36 hematophagous and nonhematophagous species. However, the most important species in epidemiologic terms is Desmodus rotundus, as these animals feed off the blood of mammals and are currently the main reservoir for the rabies virus in Brazil. They represent a potential risk to herbivores, pets and humans themselves ${ }^{15}$. In addition, the virus has been isolated in frugivorous and insectivorous species, showing that it circulates in non-hematophagous bat colonies.

Between 2000 and 2005, a total of 3586 central nervous system (CNS) samples from bats found in the city of Ribeirão Preto were processed using direct immunofluorescence antibody test (FAT), intracerebral inoculation in mice and cell culture inoculation. Of the 48 samples that were positive, one in 2000, three in 2002, 15 in 2003, one in 2004 and 28 in $2005^{3}$.

Bats from the Eumops perotis species belong to the Molossidae family and can be found in a variety of environments. Their main refuge consists of grottos, stones on high cliffs and tall buildings. In Brazil, the species has been recorded in the states of Amapá, Maranhão, Minas Gerais, Pará, Rio de Janeiro, Rio Grande do Sul and São Paulo.

Dogs were the main transmitters of human rabies in Brazil until 2003. In 2004 and 2005, however, hematophagous bats then became the main transmitters, when 22 and 42 cases of human rabies as a result of attacks by bats were recorded, respectively ${ }^{5}$.

One of the recommended epidemiologic surveillance measures is to send bats that are found outside their natural habitat and in abnormal circumstances to a diagnostic laboratory. It was as part of such surveillance that the Pasteur Institute in São Paulo was sent a specimen that had been found during the daytime in an office in the city of Ribeirão Preto, in the state of São Paulo, by the County Zoonosis Control Center. 


\section{MATERIALS AND METHODS}

Identification of the bat: The bat was registered in the Pasteur Institute under number IP1607 and identified by its morphological and morphometrical characteristics, according to GREGORIN \& TADDEI $(2002)^{12}$.

Immunofluorescence antibody test (FAT): Slides prepared from the bat's CNS were submitted to FAT, as described by DEAN et al. $(1996)^{7}$, and developed with polyclonal anti-nucleocapsid anti-rabies conjugate produced with hyperimmune rabbit serum by the Pasteur Institute in São Paulo.

Viral isolation in mice: A suspension was prepared from the bat's CNS and inoculated intracerebrally in seven 21-day-old Swiss albino mice according to the technique advocated by KOPROWSKI (1996) ${ }^{14}$.

Viral isolation in cell culture: A 20\% suspension prepared from the bat's CNS was inoculated in a N2A murine neuroblastoma cell line according to the technique described by WEBSTER \& CASEY $(1996)^{28}$ and modified by the Pasteur Institute.

Antigenic typing: The slides prepared from the CNS of the mouse that died were submitted to antigenic typing using a panel of eight monoclonal antibodies provided by CDC Atlanta, USA, to characterize the variants isolated on the American continent ${ }^{9}$.

RT-PCR and DNA sequencing: Total RNA was extracted from the bat's CNS with TRizol ${ }^{\circledR}$ Reagent (Invitrogen) according to the manufacturer's instructions. Aliquots of "Challenge Virus Standard" (CVS) fixed virus and water were used as positive and negative controls, respectively.

Reverse transcription (RT) and polymerase chain reaction (PCR) were carried out with a 21G-sense primer (ATGTAACACCTCTACAATG) and the 304-antisense primer (TTGACGAAGATCTTGCTCAT), as previously described $^{20}$. The amplified DNA fragment was purified with the GFX ${ }^{\mathrm{TM}}$ PCR DNA and Gel Band Purification kit (Amersham Bioscience), visually quantified with a Low DNA Mass Ladder (Invitrogen) and sequenced using the BigDye ${ }^{\circledR}$ Terminator v3.1 Cycle Sequencing kit (Applied Biosystems) with the sense and antisense "primers" according to the manufacturer's instructions. The reactions were then resolved in an ABI3130 automatic sequencer (Applied Biosystems ${ }^{\mathrm{TM}}$ ).
Phylogenetic analysis: A 1478-bp region corresponding to the nucleoprotein gene $(\mathrm{N})$ located between nucleotides 55 and 1533 of the PV virus (access number M13215.1) was analyzed. First, the raw sequencing data were edited using CHROMAS version 2.24 software (Copyright $^{\oplus}$ 1998-2004 Technelysium Pty Ltd.). The final consensus sequence for sample IP1607 was aligned with homologous sequences in GenBank using the CLUSTAL/W method with the Bioedit program ${ }^{13}$ and submitted to BLASTn for sequence confirmation. The alignments were then used to build a neighbor-joining distance-based phylogenetic tree using the Kimura two-parameter correction model with 1,000 replicates for statistical bootstrap support by means of the Mega 2.1 $\operatorname{program}^{17}$. The identities between the aligned sequences were calculated using the Bioedit program.

Nucleotide sequence accession numbers: The nucleotide sequence data of nucleoprotein gene was submitted to GenBank and assigned accession number EF363729.

\section{RESULTS}

Identification of the bat: The specimen was identified as a female that belonged to the family Molossidae, genus Eumops, species Eumops perotis. The specimen was later placed in the Zoology Museum of the University of São Paulo (MZUSP-32615).

FAT: The slides prepared from the bat's CNS were negative for the rabies virus as no viral antigens or inclusion bodies.

Viral isolation in mice: Only one became sick (on the $13^{\text {th }}$ day) and, after its limbs became paralyzed, died on the $17^{\text {th }}$ day. When the CNS from this mouse was submitted to FAT to confirm the presence of the viral antigen, it was found to be positive for rabies.

Viral isolation in cell culture: After incubation for $96 \mathrm{~h}$, the cells infected with the suspension produced from the CNS of the bat were submitted to fluorescent staining, and inclusion bodies.

Antigenic typing: As with Nyctinomops laticaudatus, Eptesicus furinalis and Eumops auripendulus isolates, antigenic typing of the sample did not produce reactivity compatible with the panel's pattern defined by the eight monoclonal antibodies provided by the CDC (Table 1).

RT-PCR and DNA Sequencing: Sample IP1607 was positive by

Table 1

Reaction patterns for the different antigenic variants using monoclonal antibodies

\begin{tabular}{|c|c|c|c|c|c|c|c|c|c|}
\hline \multirow[t]{2}{*}{ Isolates } & \multicolumn{9}{|c|}{ Reaction patterns (N-Mabs) } \\
\hline & $\mathrm{C} 1$ & $\mathrm{C} 4$ & C9 & $\mathrm{C} 10$ & $\mathrm{C} 12$ & $\mathrm{C} 15$ & C18 & C19 & $\mathrm{AgV}$ \\
\hline CVS/ERA-SAD/PAST & + & + & + & + & + & + & + & + & Lab \\
\hline Vampire & - & + & + & + & + & - & - & + & 3 \\
\hline Tadarida brasiliensis & - & + & + & + & + & - & - & - & 4 \\
\hline Lasiurus cinereus & $\mathrm{V} *$ & + & + & + & + & - & - & - & 6 \\
\hline Eumops perotis & - & + & - & + & + & - & - & - & $\mathbf{N C} * *$ \\
\hline Nyctinomops laticaudatus & - & + & - & + & + & - & + & + & $\mathbf{N C} * *$ \\
\hline Nyctinomops laticaudatus & - & + & - & + & - & - & - & + & $\mathbf{N C * *}$ \\
\hline Eptesicus furinalis & - & + & - & + & + & - & - & - & $\mathbf{N C} * *$ \\
\hline Eumops auripendulus & - & + & - & + & + & - & - & - & $\mathbf{N C} * *$ \\
\hline
\end{tabular}

$* \mathrm{~V}=$ weak reaction; $* * \mathrm{NC}=$ not compatible. 
RT-PCR and yielded a 1478-bp fragment. No amplification could be found in the negative control, and no extra band was detected in the reaction.

Phylogenetic analysis: A total of 1478 nucleotides of the rabies virus genome located between nucleotides 55 and 1533 were analyzed, using the PV strain as a reference. A final sequence of 1284 nucleotides situated between nucleotides 102 and 1385 in the region of the $\mathrm{N}$ gene was obtained.

The topology of the phylogenetic tree showed four distinct "clusters" (Fig. 1): 1 - samples related to insectivorous bats; 2 - samples related to hematophagous bats; 3 - fixed samples; and 4 - samples related to dogs. Cluster 1 was divided into four subclusters, called $1 \mathrm{~A}$, $1 \mathrm{~B}, 1 \mathrm{C}$ and $1 \mathrm{D}$.

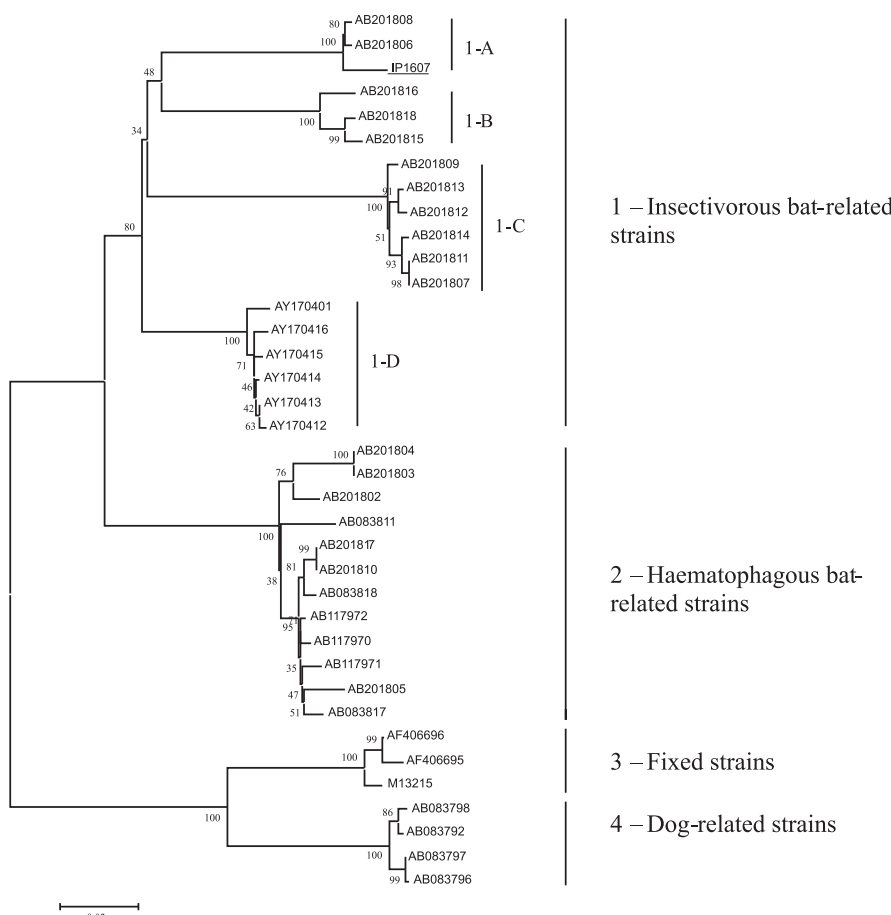

Fig. 1 - Phylogenetic tree based on the sequence of 1284 nucleotides in position 102-1385 of the rabies virus $\mathrm{N}$ gene. Phylogenetic analysis was performed using the neighbor-joining method. Sample IP1607 (accession number GenBank EF363729), which is underlined, segregated into the same group related to viruses isolated from insectivorous bats (cluster 1), genus Nyctinomops ssp. (subcluster 1A). Subcluster 1B consisted of Brazilian isolates from Molossus ssp.; subcluster 1C, Brazilian isolates from Eptesicus ssp.; and subcluster 1D, North American isolates from Eptesicus fuscus, Myotis ssp. and Lasiurus ega. The names of the samples in the tree refer to the GenBank access numbers.

Subcluster 1A (bootstrap = 100) consisted of Brazilian isolates from Nyctinomops ssp.; subcluster 1B (bootstrap = 100), Brazilian isolates from Molossus ssp.; subcluster 1C (bootstrap =100), Brazilian isolates from Eptesicus ssp.; and subcluster 1D (bootstrap = 100), North American isolates from Eptesicus fuscus, Myotis ssp. and Lasiurus ega.

Isolate IP1607 segregated into cluster 1, where isolates from insectivorous bats can be found, and segregated further into subcluster
1A, which consists of isolates from genus Nyctinomops ssp., with $98.8 \%$ identity between them. Nucleotide identities between subcluster 1A and subclusters 1B, 1C and 1D (all isolates from insectivorous bats) were $93.5 \%, 94.2 \%$ and $96.4 \%$, respectively.

\section{DISCUSSION}

The rabies virus is known, in Latin America, to have been present in hematophagous bats since the last century, when CARINI (1911) ${ }^{2}$ reported an outbreak in the state of Santa Catarina, Brazil, and related rabies in herbivores to the presence of hematophagous bats. TORRES \& QUEIROZ LIMA (1935) ${ }^{25}$ reported isolation of the virus from Diphylla ecaudata, and later was reported isolation from Diaemus youngi in the state of Alagoas, Brazil ${ }^{27}$. However, isolation of the rabies virus in bats with other feeding habits was only first recognized internationally in the 50s, when a boy was attacked by the insectivorous bat Dasypterus floridanus (now called Lasiurus intermedius). Reports of the isolation of the virus in these bats and its subsequent identification by means of antigenic and/or genetic studies have become common throughout the world in recent years ${ }^{1,10,11,18,19,23}$.

Factors related to the destruction of bats' natural ecosystems, as well as the fact that these animals are extremely versatile and can adapt to new environments, has meant that they have become synanthropic and can frequently be found in urban areas. Municipality with efficient epidemiologic surveillance, are thus more likely to find rabies-positive bats.

The existence of different rabies antigenic profiles, in isolates from $\mathrm{CNS}$ of different species of insectivorous bats was shown as early as in the first antigenic studies performed in Brazil ${ }^{11}$. Of these species, Nyctinomops laticaudatus had the greatest antigenic diversity.

Two species from genus Eumops (Eumops auripendulus ${ }^{27}$ and Eumops glaucinus ${ }^{16}$ ) have also been diagnosed as positive for rabies in Brazil, the first in one unknown city and the other in Franca, São Paulo State.

The purpose of FAT is to detect the virus in suspect samples. Thus, the negative result for the sample in this study can be attributed to the low concentration of the virus in the fragment analyzed, as its distribution in the CNS is known not to be homogeneous ${ }^{4,15,21}$. One hypothesis to explain the low concentration of the virus in the CNS could be that the animal in question was captured in the early stages of the disease $\mathrm{e}^{26}$.

The antigenic variant of the virus isolated could not be determined using the panel of monoclonal antibodies, as it had a profile that was not compatible with the patterns defined by the monoclonal antibody panel from CDC. The use of monoclonal antibodies has contributed to an understanding of the epidemiology of the rabies virus and has allowed different species to be identified within the same genotype, as well as reservoir species to be identified and viral distribution and transmission in the wild to be determined ${ }^{8,24}$. However, a number of studies have reported that rabies-virus isolates have not been antigenically characterized in Latin America using the monoclonal antibody panel provided by $\mathrm{CDC}^{6,29}$. 


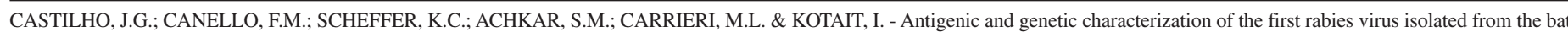
Eumops perotis in Brazil. Rev. Inst. Med. trop. S. Paulo, 50(2): 95-99, 2008.

Phylogenetic analysis was carried out to determine the genetic relationships of the rabies virus isolated from the Eumops perotis bat (IP1607). This showed that the isolates from insectivorous bats formed a large cluster separated from that formed by isolates from hematophagous bats and that this large cluster was divided into subclusters, where species-specific isolates appeared to cluster (Fig. 1). This suggests that these animals are hosts to a wide range of rabiesvirus strains, which in turn has implications for epidemiologic analysis and the assessment of bat-management strategies in urban areas.

Isolates of the rabies virus from species Nyctinomops laticaudatus segregated in subcluster 1A. This species belongs to the Molossidae family and is frequently found in the Southern, Southeastern and Central Western regions of Brazil. Both these species (Nyctinomops laticaudatus and Eumops perotis) feed exclusively on insects captured in full flight, suggesting that they may use the same ecological niches, which would explain the average intracluster identity of $98.8 \%$ and the results of the antigenic testing obtained previously ${ }^{11}$.

As a result of the increasing number of different species of insectivorous bats in Brazil infected with the rabies virus, these mammals have become potentially important transmitters of rabies to humans and domestic animals. This, together with the fact that these animals have multiple endemic cycles, makes more detailed studies of their role in the epidemiologic chain of rabies in Brazil necessary.

This study describes the first isolation of the rabies virus in an insectivorous bat from the family Molossidae, genus Eumops, species Eumops perotis in Ribeirão Preto Municipality, São Paulo, Brazil. The antigenic study suggested the high degree of identity between the virus isolated from Eumops perotis and that isolated from Nyctinomops laticaudatus, and this was confirmed by the phylogenetic study.

Genetic analysis was essential for molecular characterization of the isolate, since antigenic analysis gave an inconclusive result, as it had previously with the vast majority of variants isolated from insectivorous bats. Molecular characterization of isolates is essential in order to clarify epidemiologic aspects of rabies in bats, with a view to implementing measures related to bat management in urban areas and rabies control.

\section{RESUMO}

\section{Caracterização antigênica e genética do primeiro isolado de vírus da raiva em morcego Eumops perotis no Brasil}

No Brasil, embora os principais transmissores da raiva sejam cães e morcegos hematófagos, o papel de outras espécies, tais como morcegos insetívoros e frugívoros, merece atenção especial, uma vez que o vírus da raiva já foi isolado em 36 espécies de morcegos. Este estudo descreve o primeiro isolamento do vírus da raiva em um morcego insetívoro Eumops perotis. O animal infectado foi encontrado na cidade de Ribeirão Preto, São Paulo. O vírus foi identificado pelo teste de imunofluorescência direta (IFD) em amostras de sistema nervoso central (SNC), e o isolamento foi realizado em cultura de células N2A e em camundongos adultos. A amostra foi submetida à tipificação antigênica, utilizando um painel de oito anticorpos monoclonais (CDC/ Atlanta/USA). A sequiência de DNA do gene da nucleoproteína, localizada entre os nucleotídeos 102 a 1385, foi alinhada com seqüências homólogas presentes no GenBank, usando o método CLUSTAL/W e o alinhamento foi utilizado para a construção da árvore filogenética de distância "neighbor-joining" com o modelo K-2-P. O SNC testado foi negativo por IFD, e somente um camundongo morreu após inoculação com a suspensão do SNC do morcego. A tipificação antigênica apresentou resultado não-compatível com os padrões definidos pelo painel. A análise filogenética mostrou que o vírus isolado segregou no mesmo grupo relacionado com outros vírus isolados de morcegos insetívoros, gênero Nyctinomops ssp. (98,8\% de identidade de nucleotídeos entre elas).

\section{REFERENCES}

1. BOTVINKIN, A.D.; POLESCHUK, E.M.; KUZMIN, I.V.; BORISOVA, T.I. et al. - Novel lyssaviruses isolated from bats in Russia. Emerg. infect. Dis., 9: 1623-1625, 2003.

2. CARINI, A. - Sur une grande épizootie de rage. Ann. Inst. Pasteur, 25: 843-846, 1911.

3. CARRIERI, M.L.; OLIVEIRA, R.N.; CANELLO, F.M. et al. - Bats rabies in the period between 2000-2006, in Riberão Preto County, São Paulo State, Brazil. In: REUNIÃO INTERNACIONAL DE RAIVA NAS AMÉRICAS, 17., Brasília, 2006. Anais. p. 115 .

4. CARRIERI, M.L.; PEIXOTO, Z.M.; PACIÊNCIA, M.L.; KOTAIT, I. \& GERMANO, P.M. - Laboratory diagnosis of equine rabies and its implications for human postexposure prophylaxis. J. virol. Meth., 138: 1-9, 2006.

5. CARRIERI, M.L.; TAKAOKA, N.Y.; KOTAIT, I. \& GERMANO, P.M.L. - Diagnóstico clínico-epidemiológico da raiva humana: dados do Instituto Pasteur de São Paulo do período de 1970-2002. Bol. epidem. paul., 3(29): 2-8, 2006.

6. CISTERNA, D.; BONAVENTURA, R.; CAILlOU, S. et al. - Antigenic and molecular characterization of rabies virus in Argentina. Virus Res., 109: 139-147, 2005.

7. DEAN, D.J.; ABELSETH, M.K. \& ATANASIU, P. - Fluorescent antibody test. In: MESLIN, F-X.; KAPLAN, M.M. \& KOPROWSKI, H. Laboratory techniques in rabies. 4. ed. Geneva, World Health Organization, 1996. p. 88-95.

8. DE MATTOS, C.A.; FAVI, M.; YUNG, V.; PAVLETIC, C. \& DE MATTOS, C.C. - Bats rabies in urban centers in Chile. J. Wildlife Dis., 36: 231-240, 2000.

9. DIAZ, A.M.; PAPO, S.; RODRIGUEZ, A. \& SMITH, J.S. - Antigenic analysis of rabiesvirus isolates from Latin America and the Caribbean. Zbl. Veterinarmed. B., 41: 153-160, 1994.

10. FAVI, M.; DE MATTOS, C.A.; YUNG, V. et al. - First case of human rabies in Chile caused by an insectivorous bat virus variant. Emerg. infect. Dis., 8: 79-81, 2002.

11. FAVORETTO, S.R.; CARRIERI, M.L.; CUNHA, E.M. et al. - Antigenic typing of Brazilian rabies virus samples isolated from animals and humans, 1989-2000. Rev. Inst. Med. trop. S. Paulo, 44: 91-95, 2002.

12. GREGORIN, R. \& TADDEI, V.A. - Chave artificial para a identificação de molossídeos brasileiros (Mammalia, Chiroptera). J. neotrop. Mammal., 9: 13-32, 2002.

13. HALL, T.A. - Bioedit: a user-friendly biological sequence alignment editor and analysis program for Windows 95/98/nt. Nucl. Acids Symp. Ser., 41: 95-98, 1999.

14. KOPROWSKI, H. - The mouse inoculation test. In: MESLIN, F-X; KAPLAN, M.M. \& KOPROWSKI, H. Laboratory techniques in rabies. 4. ed. Geneva, World Health Organization, 1996. p. 80-87.

15. KOTAIT, I. \& CARRIERI, M.L. - Raiva. In: TRABULSI, L.R. \& ALTERTHUM, F. Microbiologia. 4. ed. São Paulo, Atheneu, 2004. p. 651-657. 


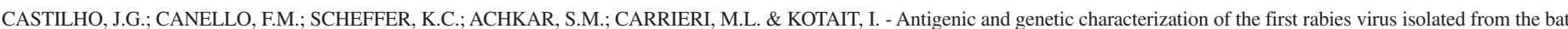
Eumops perotis in Brazil. Rev. Inst. Med. trop. S. Paulo, 50(2): 95-99, 2008.

16. KOTAIT, I.; CARRIERI, M.L.; CARNIELI JUNIOR, P. et al. - Reservatórios silvestres do vírus da raiva: um desafio para a saúde pública. Bol. epidem. paul., 4(40): 2-8, 2007.

17. KUMAR, S.; TAMURA, K.; JAKBOSEN, I.E. \& NEI, M. - MEGA 2: molecular evolutionary genetic analysis software. Tempe, Arizona State University, 2001.

18. KUZMIN, I.V.; ORCIARI, L.A.; ARAI, Y.T. et al. - Bat lyssaviruses (Aravan and Khujand) from Central Asia: phylogenetic relationships according to N, P and G gene sequences. Virus Res., 97: 65-79, 2003.

19. NADIN-DAVIS, A.S.; HUANG, W.; ARMSTRONG, J. et al. - Antigenic and genetic divergence of rabies viruses from bat species indigenous to Canada. Virus Res., 74: 139-156, 2001.

20. ORCIARI, L.A.; NIEZGODA, M.; HANLON, C.A. et al. - Rapid clearance of SAG-2 rabies virus from dogs after oral vaccination. Vaccine, 19: 4511-4518, 2001.

21. PEIXOTO, Z.M.P.; CUNHA, E.M.S.; SACRAMENTO, D. et al. - Rabies laboratory diagnosis: peculiar features of samples from equine origin. Braz. J. Microbiol., 31: $72-75,2000$.

22. SIMMONS, N.B. - Order Chiroptera. In: WILSON, D.E. \& REEDER, D.M. Mammals species of the world: a taxonomic and geographic reference. 3. ed. Baltimore, Johns Hopkins University Press, 2005. p. 312-529.
23. SMITH, J.S.; ORCIARI, L.A. \& YAGER, P. A. - Molecular epidemiology of rabies in the United States. Semin. Virol., 6: 387-400, 1995.

24. SMITH, J.S. - Monoclonal antibody studies of rabies in insectivorous bats of the United States. Rev. infect. Dis., 10 (suppl. 4): S637-S643, 1988.

25. TORRES, S. \& QUEIROZ LIMA, E. - A raiva nos morcegos hematophagos. Rev. Dep. nac. Prod. animal, 2(416): 385-407, 1935.

26. TRIMARCHI, C.V. \& SMITH, J.S. - Diagnostic evaluation. In: JACKSON, A. \& WUNNER, W.H. Rabies. USA, Academic Press, 2002. p. 307-349.

27. UIEDA, W.; HAYASHI, M.M.; GOMES, L.H. \& SILVA, M.M.S. - Espécies de quirópteros diagnosticadas com raiva no Brasil: Bol. Inst. Pasteur (S. Paulo), 1(2): 17-36, 1996.

28. WEBSTER, W.A. \& CASEY, G.A. - Virus isolation in neuroblastoma cell culture. In: MESLIN, F.X.; KAPLAN, M.M. \& KOPROWSKI, H. Laboratory techniques in rabies. 4. ed. Geneva, World Health Organization, 1996. p. 96-104.

29. YUNG, V.; FAVI, M. \& FERNANDEZ, J. - Genetic and antigenic typing of rabies virus in Chile. Arch. Virol., 147: 2197-2205, 2002.

Received: 27 March 2007

Accepted: 18 February 2008 